\title{
Exploration of Local Microorganisms from Rumen and Their Potential to Make Silage from Agricultural Waste
}

\author{
Listya Purnamasari1,*, Hari Purnomo², and Hidayat Bambang Setyawan ${ }^{1}$ \\ ${ }^{1}$ Department of Animal Husbandry, Faculty of Agriculture, University of Jember, Jl. Kalimantan No. 37, Jember 68121, Indonesia. \\ ${ }^{2}$ Department of Agrotechnology, Faculty of Agriculture, University of Jember, Jl. Kalimantan No. 37, Jember 68121, Indonesia. \\ *Corresponding author: listyap.faperta@unej.ac.id
}

\section{KEYWORDS \\ Agricultural waste \\ Local microorganisms \\ Rumen \\ Silage}

SUBMITTED 17 September 2020

REVISED 25 October 2020

ACCEPTED 31 October 2020

\begin{abstract}
Agricultural wastes are very diverse in type and have low nutrient values, especially in lignin and cellulose, which are difficult to digest. One way of overcoming this problem is by biological treatment using microorganisms, also known as silage. The availability of bio-activators that are both costefficient and easy to make further suggests that using local microorganisms may be an effective possible solution. This study focused on processing food crop waste (corn leaves) into silage using local microorganisms as the bio-activators. Research took place in the Agrotechnology Laboratory, University of Jember. The experimental design was completely randomized with four treatments: Treatment 1 (rumen), Treatment 2 (rumen + banana humps), Treatment 3 (rumen + petung bamboo shoots), and Treatment 4 (rumen + gamal leaves). The parameters tested were local microorganism quality ( $\mathrm{pH}$, total microbial, and organoleptic) and silage quality (nutrient composition, $\mathrm{pH}$, and organoleptic). After three weeks, the organoleptic local microorganism test results in all treatments showed clear colors, an acidic aroma, small number of fungi, and normal pH (3-5). In terms of silage quality, the resulting local microorganisms could be used as a bio-activator in the silage fermentation process, with the maturity level indicated by a color change (green to brownish green), sweet and acidic aroma, softer tape and texture, and $\mathrm{pH}$ of 4-6. The proximate test results of this silage feed showed better nutrient content in the addition of formulations in the manufacture of local microorganisms. Petung bamboo shoots, gamal leaves, and banana humps can increase the nutrient content, mainly the protein. We therefore conclude that local microorganisms from the rumen and local materials can be used as activator materials in making silage from corn leaves with an increase in the value of waste nutrients.
\end{abstract}

(c) The Author(s) 2020. This article is distributed under a Creative Commons Attribution-ShareAlike 4.0 International license.

\section{INTRODUCTION}

The availability of ruminant feed in the dry season is very limited, so it is necessary to process and preserve forage with abundant availability during the rainy season. Agricultural waste is one of the potentially abundant feedstuffs available during the harvest season, so preservation efforts are needed to extend storage capacity and increase digestibility. One thing that can be done to overcome this problem is biological treatment using microorganisms known as silage as a bio-activator (Bestari et al. 2000; Thalib et al. 2000; Haryanto et al. 2004). Silage is made in an anaerobic atmosphere with the growth of microorganisms that can lower $\mathrm{pH}$, making it acidic. Silage usually requires several types of microorganisms that are mixed into the feed composition to be fermented. The example microorganisms are Lactobacillus sp., Saccaromyces cereviceae, Aspergillus oryzae, starbio, Em4, Probion, and so on.

This study focuses on processing food crop wastes, namely corn leaves, into silage as an animal feed with local microorganisms as the bio-activators on silage processing, which has been an important source of ruminant diets. The local microorganisms used were those that can be made from local materials that are themselves easily obtained in the environment (Han-kyu 2010; Sutari 2010). These microorganisms were isolated from various materials such as human food, soil, and the digestive tract of livestock.

The availability of bio-activators that are cheap and easy to manufacture and have good microorganism activity in remodeling agricultural waste, must also be considered. The quality and stability of silage can be enhanced via the application of microbial additives (Bernardes et al. 2018; Chen et al. 2020). One of the easy and inexpensive sources of microorganisms to use in producing local microorganisms is the contents of the rumen (Purwasasmita and Kabelan 2009). Other ingredients that can potentially be used to make local microorganisms are banana humps, bamboo shoots, and gamal leaves. Local microorganisms made from organic waste contain microbes and chemical properties such as $\mathrm{pH}$ that affect the growth of the microbes (Suhastyo et al. 2013). Based on this potential, basic research is needed to determine its potential and its use in producing quality silage. The use of microorganisms in the field, either in the form of bio-activators or as fermentation products for agricultural wastes, must be carried out optimally so that the availability of feed can continue to be guaranteed throughout the year and enable the creation of a cleaner environment free of contamination. 


\section{MATERIALS AND METHODS}

\subsection{Materials}

The tools used in making local microorganisms were plastic jars, plastic hoses, plastic bottles, and plasticine. The materials used were rumen from a slaughterhouse, molasses, banana humps, Dendrocalamus asper (petung or giant bamboo) shoots, Gliricidia sepium (gamal) leaves, rice washing water, and coconut water. The proliferation of local microorganisms was carried out by making formulations from several materials according to treatment (Table 1). Making the local microorganisms was carried out by mixing all of the components of the material for 21 days in a plastic bucket and then they were anaerobically conditioned.

The equipment used in this local microorganism test comprised sample bottles, Petri dishes, measuring cups, Erlenmeyer flasks, autoclave, magnetic stirrers, incubators, ovens, rulers, microscopes, glass objects, and cover glass, digital scales, test tubes, and tube racks, pipette drops, stirring rods, aluminum foil, Laminar Air Flow (LAF), refrigerators, bunsen burners, ose, $\mathrm{pH}$ meters, stationery, and digital cameras. The material used was a sample of each local microorganism formulation, distilled water, luria berthani medium (LB), 96\% alcohol, immersion oil, spirits, and tissue. Finally, the material used for making silage encompassed corn leaves which had been chopped with a size of 5-10 cm using a chopper, molasses, rice bran, and local microorganisms that had been made beforehand (Table 2).

\subsection{Silage preparation and observation}

The local microorganism sample was measured based on $\mathrm{pH}$ using a $\mathrm{pH}$ meter and then grown in the LB media, and we then looked at the total of the microorganisms contained in it. The chemical tests carried out comprised the analysis of the $\mathrm{N}, \mathrm{P}, \mathrm{K}$, and $\mathrm{C} / \mathrm{N}$ ratio. Organoleptic physical testing was also carried out on the local microorganisms every week, namely on color, aroma, and texture.

Measuring $\mathrm{N}$ levels was done by taking $0.25 \mathrm{ml}$ of local microorganism and putting it into a Kjeldahl flask, along with $2.5 \mathrm{ml}$ sulfuric acid and $0.25 \mathrm{~g}$ selenium catalyst. The solution was digested until it clarified, and then added to a storage solution prepared in a $125 \mathrm{ml}$ Erlenmeyer flask con-

TABLE 1. Formulation of local microorganism as the treatment.

\begin{tabular}{lcccc}
\hline Ingredients & \multicolumn{4}{c}{ Treatment } \\
\cline { 2 - 5 } & 1 & 2 & 3 & 4 \\
\hline Rumen & $500 \mathrm{~g}$ & $500 \mathrm{~g}$ & $500 \mathrm{~g}$ & $500 \mathrm{~g}$ \\
Banana humps & - & $1000 \mathrm{~g}$ & - & - \\
Petung bamboo shoots & - & - & $1000 \mathrm{~g}$ & - \\
Gamal leaves & - & - & - & $1000 \mathrm{~g}$ \\
Molasses & $0.1 \mathrm{l}$ & $0.1 \mathrm{l}$ & $0.1 \mathrm{l}$ & $0.1 \mathrm{l}$ \\
Coconut water & $1 \mathrm{l}$ & $1 \mathrm{l}$ & $1 \mathrm{l}$ & $1 \mathrm{l}$ \\
Rice washing water & $1 \mathrm{l}$ & $1 \mathrm{l}$ & $1 \mathrm{l}$ & $1 \mathrm{l}$ \\
\hline
\end{tabular}

sisting of a $4 \% \mathrm{H}_{3} \mathrm{BO}_{3}$ solution and two or three drops of BCGMR (Brom Cresol Green and Methyl Red), then distilled. The distillation process was stopped if more bubbles were coming out of the storage solution. The distillation results were titrated with $0.01 \mathrm{~N} \mathrm{HCl}$.

Phosphorus levels $\left(\mathrm{P}_{2} \mathrm{O}_{5}\right)$ were measured by mixing 2 $\mathrm{ml}$ of local microorganism with $10 \mathrm{ml}$ of $25 \% \mathrm{HCl}$ and stored for \pm 24 hours. Subsequently, $2 \mathrm{ml}$ of the mixture of the liquid and added with $18 \mathrm{ml}$ of distilled water. The diluted solution was added to $0.5 \mathrm{ml}$ of $\mathrm{NH}_{4}$ molybdate and 2-3 drops of $\mathrm{SnCl}_{2}$, then measured using a spectrophotometer with a wavelength of $693 \mathrm{~mm}$. The measurement results obtained were compared with the standard curve.

The level of potassium (K) was measured by adding $1 \mathrm{ml}$ of local microorganism with $25 \mathrm{ml}$ of $25 \% \mathrm{HCl}$ for deconstruction. A mixture of $65 \% \mathrm{HNO}_{3}$ and $\mathrm{HClO}_{4}$ with a ratio of 2:1 and then re-construction was carried out by adding $10 \mathrm{ml}$ of $37 \% \mathrm{HCl}$ until the sample was white. The results of the destruction were diluted to $250 \mathrm{ml} ; 5 \mathrm{ml}$ was then piped and diluted to $10 \mathrm{ml}$. Then it was measured using an atomic absorption spectrophotometer.

The stages of silage making were carried out with the main raw material of corn leaves using local microorganisms which has been made by adding an energy substrate, molasses. Silage fermentation was carried out anaerobically in a clear plastic bag to facilitate organoleptic physical testing. To make silage, all ingredients mixed on a tarpaulin were then inserted into a clear plastic silo. The process of inserting the material into the silo was gentle and slowly, followed by pressing until it felt solid and there was no more air in the plastic silo. The fermentation process was carried out for four weeks.

Silage observation was carried out after one week, three weeks, and five weeks of fermentation, and the observed parameters were: the proximate test of nutrient quality including crude protein crude fiber, crude fat, dry material, ash, and nitrogen free extract. The physical characteristics of silage were evaluated by describing its physical properties, including aroma, color, texture, and calculating the percentage of fungi by three trained panelists. The $\mathrm{pH}$ measurements were carried out using a $\mathrm{pH}$ meter on newly opened silage, from which $10 \mathrm{~g}$ was taken and mixed with $100 \mathrm{~mL}$ distilled water using a blender aid at high speed for $30 \mathrm{~s}$.

\subsection{Statistical analyses}

The design used was a completely randomized design. Data were processed by analysis of variance (ANOVA) using SPSS software, followed by Duncan multiple range tests.

\section{RESULTS}

Every week, organoleptic physical tests (color, aroma, and number of fungi) and the $\mathrm{pH}$ were measured, the results of the former of which are shown in Table 3. The organoleptic physical test results showed that the local microorganism that had been made showed signs of success with rather

TABLE 2. Treatment of silage formulation from different local microorganisms.

\begin{tabular}{|c|c|c|c|c|}
\hline Ingredients & Treatment 1 & Treatment 2 & Treatment 3 & Treatment 4 \\
\hline Corn leaves & $500 \mathrm{~g}$ & $500 \mathrm{~g}$ & $500 \mathrm{~g}$ & $500 \mathrm{~g}$ \\
\hline Molasses & $0.1 \mathrm{l}$ & $0.1 \mathrm{l}$ & $0.1 \mathrm{l}$ & $0.1 \mathrm{l}$ \\
\hline Local microorganism (MOL) & 0.01 I from MOL (rumen) & $\begin{array}{l}0.01 \text { I from MOL (rumen }+ \\
\text { banana humps) }\end{array}$ & $\begin{array}{l}0.01 \text { I from MOL (rumen }+ \\
\text { petung bamboo shoots) }\end{array}$ & $\begin{array}{l}0.01 \text { I from MOL (rumen }+ \\
\text { gamal leaves) }\end{array}$ \\
\hline
\end{tabular}


TABLE 3. Organoleptic test results of local microorganisms, weeks 1-3.

\begin{tabular}{|c|c|c|c|c|c|c|c|c|c|c|c|c|}
\hline \multirow[t]{2}{*}{ Treatment type } & \multicolumn{3}{|c|}{ Treatment 1} & \multicolumn{3}{|c|}{ Treatment 2} & \multicolumn{3}{|c|}{ Treatment 3} & \multicolumn{3}{|c|}{ Treatment 4} \\
\hline & Week 1 & Week 2 & Week 3 & Week 1 & Week 2 & Week 3 & Week 1 & Week 2 & Week 3 & Week 1 & Week 2 & Week 3 \\
\hline Color & ++ & + & + & +++ & ++ & + & +++ & ++ & + & +++ & ++ & + \\
\hline Aroma & + & ++ & ++ & + & ++ & ++ & + & ++ & ++ & + & ++ & ++ \\
\hline Number of fungi & + & + & + & + & + & ++ & + & ++ & ++ & + & + & ++ \\
\hline
\end{tabular}

Color: + = clear, ++ = rather muddy, +++ muddy; aroma: + = rather acidic, ++ = acidic, +++ = very acidic; number of fungi: + = very small, ++ = small, +++ = rather big, $++++=$ bigger, $+++++=$ biggest.

clear colors, the sour aroma of fermentation, and the number of fungi that appeared slightly in all treatments.

The results of the $\mathrm{pH}$ measurements are presented in Figure 1. The degree of acidity $(\mathrm{pH})$ of the local microorganisms indicated that bacteria that grew on the media were acidic bacteria, such as lactic acid bacteria and Lactobacillus. The normal $\mathrm{pH}$ content of the MOL was 3-5.

The chemical test on local microorganisms that was carried out comprised the measurement of NPK and C/N ratio and the measurement of the number of microorganisms, namely Lactobacillus bacteria, with the results presented in Figure 2 for total $\mathrm{N}$ and $\mathrm{P}_{2} \mathrm{O}_{5}$, Figure 3 for $\mathrm{K}_{2} \mathrm{O}$, $\mathrm{C}$-Organic and $\mathrm{C} / \mathrm{N}$ ratio, and Figure 4 for the number of Lactobacillus.

At 1, 2, and 3 weeks of treatment, organoleptic physical tests were performed on the silage, encompassing color, aroma, texture, and number of fungi (Table 4). These results showed that silage had been successfully made at week 3 , and already had textures that could be consumed by livestock properly.

Silage $\mathrm{pH}$ measurement was carried out at three weeks. The selection of the 3rd week as the initial $\mathrm{pH}$ calculation was due to the optimization of the silage fermentation process; i.e., after week 3 under anaerobic conditions. The re-

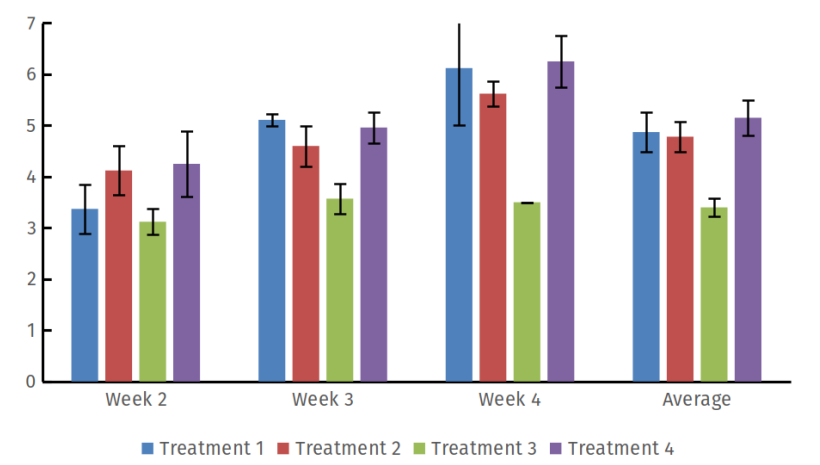

FIGURE 1. Results of local microorganisms' pH at 2, 3, and 4 weeks old.

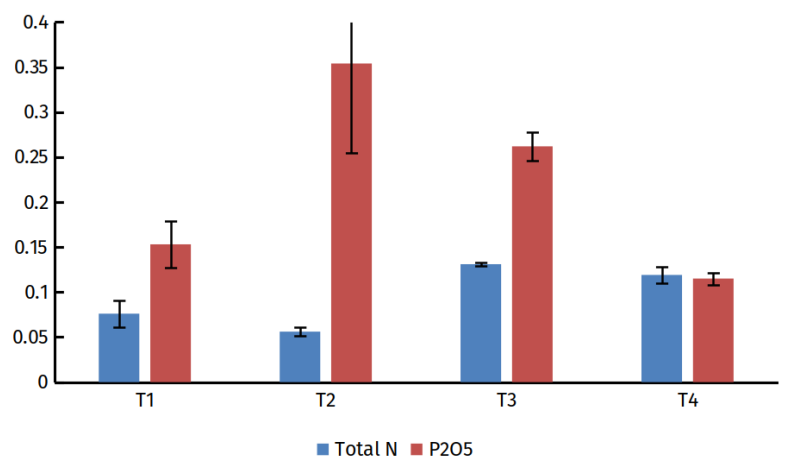

FIGURE 2. Total $\mathrm{N}$ and $\mathrm{P}$ in local microorganisms. sults of the silage $\mathrm{pH}$ measurements are presented in Figure 5 . The degree of normal cells' acidity was $4-6$. The silage results showed that silage made until the third week was in a normal condition.

The proximate test of feed was carried out in the Bioscience Laboratory of State Polytechnic of Jember. The proximate test results revealed that the fermentation treatment using local microorganisms can increase the forage protein content. The proximate test results of corn leaf silage can be seen in Figure 6.

\section{DISCUSSION}

Factors that determine the quality of the MOL solution are the fermentation media, the level of raw materials or substrate, the shape and nature of the microorganism that are active in the fermentation process, $\mathrm{pH}$, temperature, duration of fermentation, and $\mathrm{C} / \mathrm{N}$ ratio in the material (Besterfield 2003). Our results showed that the $\mathrm{pH}$ level of the local microorganisms was still in a normal condition until the 3rd week. At the 5 th week, the $\mathrm{pH}$ content of Treatment 1 and Treatment 4 began to become abnormal, indicating that the content of lactic acid bacteria contained in the MOL began to decline with time.

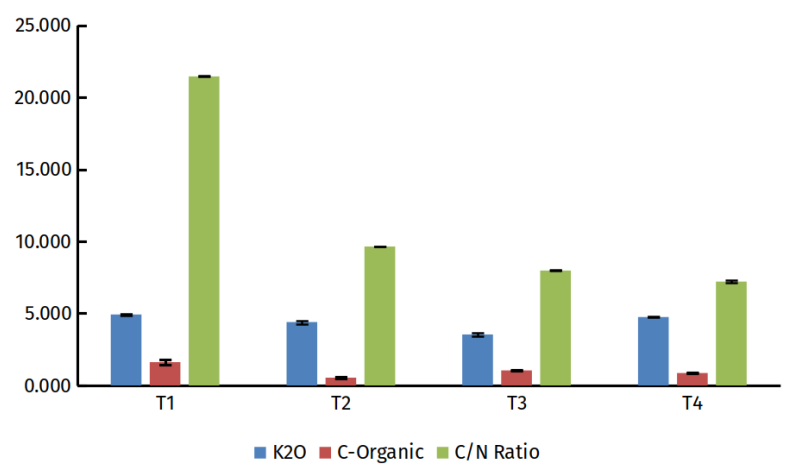

FIGURE 3. Total $\mathrm{K}_{2} \mathrm{O}$, C-Organic, and $\mathrm{C} / \mathrm{N}$ ratio in local microorganisms.

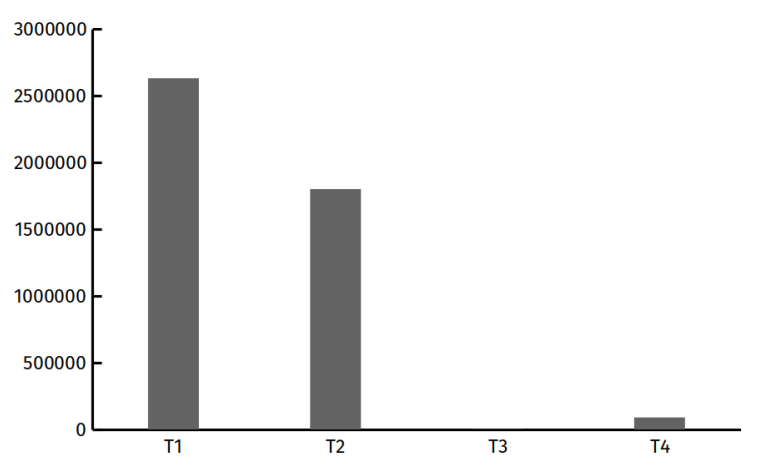

FIGURE 4. Number of Lactobacillus in local microorganisms. 
TABLE 4. Organoleptic physical test results after 1, 2, and 3 weeks of treatment.

\begin{tabular}{|c|c|c|c|c|}
\hline Treatment type & Treatment 1 & Treatment 2 & Treatment 3 & Treatment 4 \\
\hline \multicolumn{5}{|c|}{ Week 1} \\
\hline Fungi & + & ++ & ++ & ++ \\
\hline Smell & Rather acidic & Acidic & Rather acidic & Rather acidic \\
\hline Color & Browny green & Browny green & Browny green & Browny green \\
\hline \multicolumn{5}{|c|}{ Week 2} \\
\hline Fungi & ++ & ++ & +++ & ++ \\
\hline Smell & Acidic & Acidic & Acidic & Acidic \\
\hline Color & Brown & Brown & Brown & Brown \\
\hline \multicolumn{5}{|c|}{ Week 3} \\
\hline Fungi & ++ & +++ & +++ & +++ \\
\hline Smell & Acidic & Acidic & Acidic & Acidic \\
\hline Color & Brown & Brown & Brown & Brown \\
\hline
\end{tabular}

Fungi: + = very small, ++ = small, +++ = rather big, $++++=$ bigger, +++++ = biggest.

These microorganisms produce cellulase enzymes that are able to hydrolyze cellulose into oligosaccharides and eventually become glucose, which functions as a source of carbon and nutrients for plant growth. Cellulolytic microorganisms have the ability to grow on cellulose and can decompose cellulose in response to cellulose in their environment by producing cellulase enzymes. The cellulase enzyme is able to hydrolyze cellulose into dissolved sugar which is then used as a source of carbon and nutrients for plants. The activity of cellulolytic microorganisms is generally influenced by the availability of nitrogen, temperature, aeration, humidity, $\mathrm{pH}$, and the presence of carbohydrates. At a low $\mathrm{pH}$, the fungus plays an active role in overhauling cellulose and the process is relatively faster at a $\mathrm{pH}$ range around 5 (Lynd et al. 2002).

The treatment that resulted in the lowest $\mathrm{pH}$ content (most acidic), namely Treatment 3 , was that with the addition of petung bamboo shoots to the local microorganism formula, and the treatment with a $\mathrm{pH}$ closest to normal was that in Treatment 4, which was the addition of gamal leaves. The low $\mathrm{pH}$ content was influenced by the microbial activity contained in it. Based on the research of of banana humps Suhastyo et al. (2013), the MOL pH tended to be stable at an average of 4-4.5 in the first to third weeks. The $\mathrm{pH}$ value of the rumen MOL in composting, meanwhile, also showed some stability from the first to the fourth weeks, with an optimal value of 5.5-8.0 and 5.38, according to Firdaus et al. (2014) and Budiyani et al. (2016), respectively.

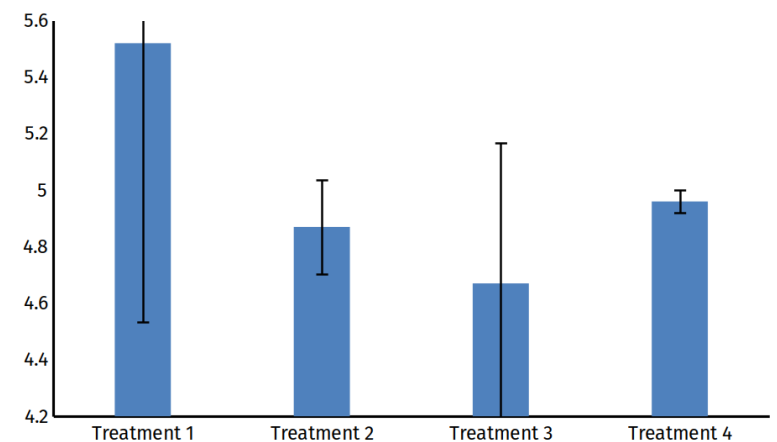

FIGURE 5. Average pH of silage after fermentation.
Ruminants' rumen fluid contains bacteria, protozoa and fungi (Oktavia et al. 2012). The concentration of bacteria ranges from 109 per cc of rumen content, while protozoa ranges 105-106 per cc of rumen content (Tillman et al. 1991). Rumen microorganisms are able to utilize carbohydrate fibers because they contain cellulolytic microorganisms, such as Butyrivibrio, Ruminococcus, and Piromonas communis. In addition, there are also amylolytic bacteria that can break down starch, namely Clostridium locheidii; proteolytic bacteria, namely Proteus, Corynebacterium, and Micrococcus; and lipolytic bacteria, namely Veillonella alcalescens (Hungate 1975). In many cases, rumen content is not utilized optimally or simply discarded, resulting in environmental pollution (Komarawidjaja 2009). The amount of Lactobacillus was highest in Treatment $1(2.63 \times 106)$, followed by Treatment $2(1.86 \times 106)$, Treatment $4(8.96 \times 104)$, and Treatment $3(1.63 \times 103)$. The differences in these values depend on the amount of organic material composition given (Seni et al. 2013).

The highest organic content of local microorganisms solution was found in Treatment 1 and decreased respectively in Treatments 3,4 , and 2 . This was due to differences in the composition of the organic matter in each treatment. The activity of the microorganisms overall depends on the amount of organic material composition given (Seni et al. 2013). Microorganisms need a carbon source for both energy and reproduction (Hidayat 2006). The results of the observation of the total $\mathrm{N}$ of the local microorganisms con-

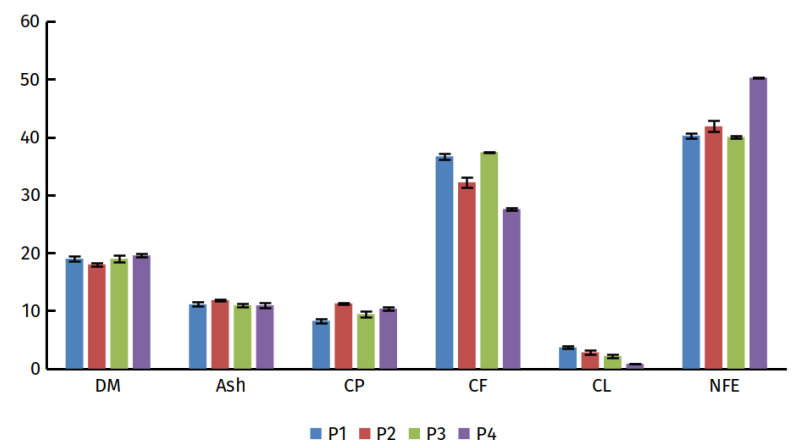

FIGURE 6. Proximate results of corn leaf silage. 
tent showed that the more energy sources that could be broken down, the more $\mathrm{N}$ was released in the local microorganisms solution. As such, the $\mathrm{N}$ value of Treatment 3 was the highest, followed by Treatments 4 and 1, and finally Treatment 2 with the lowest. The content of the basic ingredients used in local microorganisms affects the $\mathrm{N}$-total (Purwasasmita and Kabelan 2009). Our results showed that the C-organic content of the quality of the MOL solution had no significant effect. These results are in accordance with those of Budiyani et al. (2016), who found that the Corganic content of the MOL solution decreased with the length of fermentation and the materials used. Harizena (2012) also observed that the C-organic content decreased because it had been broken down into simpler compounds by the microorganisms present in the MOL solution. Organic compounds will decrease and inorganic compounds will increase. The $\mathrm{C} / \mathrm{N}$ ratio is the result of a comparison between carbohydrates and nitrogen contained in a material. A higher the $\mathrm{N}$-total content of the form will result in a decrease in the $\mathrm{C} / \mathrm{N}$ ratio, causing mineralization. Mineralization of $\mathrm{N}$ is the formation of inorganic nitrogen from organic nitrogen with ammonification and nitrification processes (Sutari 2010).

The success of silage making depends on several factors, including the population of lactic acid, physical properties, and forage chemicals used, as well as environmental conditions (Tatra 2010). Silage is made in an anaerobic environment and with the growth of certain microorganisms that make silage $\mathrm{pH}$ low (i.e., acidic), silage is subsequently made durable for several months. Naturally, microorganisms such as lactic acid bacteria will completely turn their own soil. The silage process can be accelerated by adding acid-forming microorganisms to the forage that will be fermented. Anaerobic bacteria that can grow and develop on acidic soils include Clostridium, Syntrobacter wolinii, and Syntrophomonas wolfei (Sim 2005). Silage can be stored for years when the storage conditions remain anaerobic, tight, and there are no leaks (Lubis 1963). However, high-quality silage is often associated with oxidative deterioration after opening because its residual soluble carbohydrate and high concentration of lactic acid could be used as growing substrates by yeasts to initiate spoilage (Bai et al. 2020). The poor fermentation quality of silage is caused by the fermentation of undesirable microorganisms, like Clostrodium and Enterobacter (Ni et al. 2020).

The test results showed that the highest protein content was obtained in Treatment 2, which was the banana hump formulation, and then Treatment 4 (gamal leaves), Treatment 3 (petung bamboo shoots), and lastly Treatment 1 (control of the addition of formulation). It is suspected that the addition of formulations to both gamal leaves, banana humps, and bamboo shoots can increase the microbial content, which helps the fermentation process and increases the biomass's production of protein-producing microbes. The process of making silage also helps in increasing the digestibility of crude fiber feed ingredients.

Some studies suggest that silage making can be done with the help of bio-activators derived from fluids, fresh buffalo rumen, or anaerobic bacterial isolates from buffalo rumen fluid as an inoculum (Bestari et al. 2000; Sasongko and Sugoro 2004). Silage or fermentation processes can increase the value of forage digestibility, such as rice straw and improve the quality of forage nutrients (Bestari et al. 2000; Thalib et al. 2000; Haryanto et al. 2004). The process of decomposing organic compounds will produce energy and the conversion of substrate into new products by mi- crobes (Madigan et al. 2011; Muhidin 2001). Fardiaz (1992) also noted that the fermentation process can increase the nutritional value of ingredients that have low quality, function in preserving feed ingredients, and reduce or eliminate anti-nutrients or poisons in feed ingredients. The addition of microorganisms in the fermentation process is thus useful for accelerating the fermentation process (Indriani 1999), and a good candidate of local microorganisms for ensiling will mainly be characterized by fast growth, resistance against low $\mathrm{pH}$, and quick production of desirable metabolites, such as lactic acid, at a wide range of growth temperatures (Chen et al. 2020).

\section{CONCLUSIONS}

Rumen content, banana humps, and bamboo shoots have excellent potential to be used as materials in the productions of local microorganisms. This was supported by the results of local microorganisms' organoleptic tests after a period of three weeks, such as a clear color, sour smell, a small amount of fungi, and normal $\mathrm{pH}$ of 3-5. The local microorganisms that were made were used in the process of fermenting animal feed silage from agricultural waste, namely corn silage. In terms of silage quality, our test results showed that the local microorganisms produced could be used as a bio-activator in the silage fermentation process. After fermentation for three weeks, the level of maturity was indicated by a color change of green to brownish green and a sweet and sour aroma, such as softer tape, and texture with acidic $\mathrm{pH}$ concentration of 4-6. The proximate test results of the silage feed made using local microorganisms also showed a better nutrient content in the addition of formulations in the manufacture of local microorganisms. Petung bamboo shoots, gamal leaves, and banana humps can increase the nutrient content, mainly that of protein.

\section{ACKNOWLEDGMENTS}

The authors would like to thank the Institute for Research and Community Service to the Community (LP2M), University of Jember, who provided financial assistance through Grant Number SP DIPA: 042.01.2.400922/2018.

\section{AUTHORS' CONTRIBUTIONS}

LP, HP conceived and designed the experiments. LP performed the experiments and analyzed the data. HP and HBS contributed reagents, materials, and analysis tools. LP drafted the manuscript. All authors read and approved the final version of the manuscript.

\section{COMPETING INTERESTS}

The authors declare no competing interests.

\section{REFERENCES}

Bai J, Xu D, Xie D, Wang M, Li Z, Guo X. 2020. Effects of antibacterial peptide-producing Bacillus subtilis and Lactobacillus buchneri on fermentation, aerobic stability, and microbial community of alfalfa silage. Bioresour Technol. 315:123881. doi:10.1016/j.biortech.2020.123881.

Bernardes T, Daniel J, Adesogan A, McAllister T, Drouin P, Nussio L, Huhtanen P, Tremblay G, Bélanger G, Cai Y. 2018. Silage review: Unique challenges of silages made in hot and cold regions. J Dairy Sci. 101(5):4001-4019. doi:10.3168/jds.2017-13703. 
Bestari J, Thalib A, Hamid H. 2000. Pengaruh kombinasi pemberian pakan silase jerami padi cairan rumen kerbau dan molase terhadap pertambahan bobot badan sapi peranakan ongole [The feeding effect of rice-straw silage mixed with buffalo's ruminal liquid and mollase on daily gain of PO cattle]. Prosiding Seminar Nasional Teknologi Peternakan dan Veteriner. Bogor: Puslitbang Peternakan. p. 242-250.

Besterfield DEUH. 2003. Total quality management. 3rd edition. New Jersey: Pearson Education International.

Budiyani NK, Soniari NN, Sutari NWS. 2016. Analisis kualitas larutan mikroorganisme lokal (MOL) bonggol pisang [Analysis of local microorganism (MOL) solution quality based on banana weevil]. Jurnal Agroteknologi Tropika. 5(1):63-72.

Chen L, Bai S, You M, Xiao B, Li P, Cai Y. 2020. Effect of a low temperature tolerant lactic acid bacteria inoculant on the fermentation quality and bacterial community of oat round bale silage. Anim Feed Sci Technol. 269:114669. doi:10.1016/j.anifeedsci.2020.114669.

Fardiaz S. 1992. Mikrobiologi pangan 1 [Food microbiology 1]. Jakarta: Gramedia.

Firdaus F, Purwanto BP, Salundik S. 2014. Dosis penggunaan mikroorganisme lokal (MOL) ragi tempe dan isi rumen untuk pengomposan [Dose of using local microorganism (MOL) of tempe yeast and rumen content for composting]. Jurnal Ilmu Produksi dan Teknologi Hasil Peternakan. 2(1):257-261.

Han-kyu C. 2010. Natural farming. Korea: CGNF Company.

Harizena IND. 2012. Pengaruh jenis dan dosis MOL terhadap kualitas kompos sampah rumah tangga [Effect of type and dose of mol on the quality of household waste compost; bachelor's thesis]. [Denpasar]: Universitas Udayana.

Haryanto B, Lema CAV, Yulianti A, Surayah S, Abdurrahman A. 2004. Peningkatan degradasi serat jerami padi melalui proses fermentasi dan suplementasi zinc-methionin [Increased degradation of rice straw fiber through fermentation processes and zincmethionin supplementation]. Prosiding Seminar Nasional Teknologi Peternakan dan Veteriner. Bogor: Puslitbang Peternakan. p. 805-812.

Hidayat N. 2006. Mikrobiologi industri [Industrial microbiology]. Yogyakarta: Andi Offset.

Hungate RE. 1975. The rumen microbial ecosystem. Annu Rev Ecol Syst. 6(1):39-66. doi:10.1146/annurev.es.06.11 0175.000351.

Indriani YH. 1999. Membuat kompos secara kilat [Make compost in a flash]. Jakarta: Penebar Swadaya Grup.

Komarawidjaja W. 2009. Karakteristik dan pertumbuhan konsorsium mikroba lokal dalam media mengandung minyak bumi [Characteristics and growth of local microbial consortia in petroleum-containing media]. Jurnal Teknologi Lingkungan. 10(1):114-119. doi:10.29122/j tl.v10i1.1510.

Lubis DA. 1963. Ilmu makanan ternak [Animal feed science]. Jakarta: Pembangunan.

Lynd LR, Weimer PJ, van Zyl WH, Pretorius IS. 2002. Microbial cellulose utilization: fundamentals and biotechnology. Microbiol Mol Biol Rev. 66(3):506-577. doi: 10.1128/mmbr.66.3.506-577.2002.

Madigan MT, Martinko JM, Parker J. 2011. Biology of microorganisms. 12th edition. New York: Prentice Hall International.

Muhidin D. 2001. Agroindustri papain dan pektin [Papain and pectin agroindustry]. Jakarta: Penebar Swadaya Grup.

Ni K, Wang X, Lu Y, Guo L, Li X, Yang F. 2020. Exploring the silage quality of alfalfa ensiled with the residues of astragalus and hawthorn. Bioresour Technol. 297:122249. doi:10.1016/j.biortech.2019.122249.

Oktavia DA, Mangunwidjaja D, Wibowo S, Sunarti TC, Rahayuningsih M. 2012. Pengolahan limbah cair perikanan menggunakan konsorsium mikroba indigenous proteolitik dan lipolitik [The processing of fishery wastewater using a consortium of indigenous proteolytic and lipolytic microbes]. Agrointek. 6(2):65-71.

Purwasasmita M, Kabelan K. 2009. Mikroorganisme lokal sebagai pemicu siklus kehidupan dalam bioreaktor tanaman [Local microorganisms as triggers of the life cycle in plant bioreactors]. Prosiding Seminar Nasional Teknik Kimia Indonesia. Bandung.

Sasongko WT, Sugoro I. 2004. Wet fermentation of rice straw cv. atomita 4 using a mixed inoculum of facultative anaerobic bacteria in buffalo rumen. Risalah Seminar Ilmiah Penelitian dan Pengembangan Aplikasi Isotop dan Radiasi [Minutes of Scientific Seminar on Research and Development of Isotopes and Radiation Applications]. Jakarta: Badan Tenaga Nuklir Nasional. p. 171-174.

Seni IAY, Atmaja IWD, Sutari NWS. 2013. Analisis kualitas larutan MOL (mikroorganisme lokal) berbasis daun gamal (Gliricidia sepium) [Analysis of the quality of the MOL (local microorganism) solution based on gamal leaf (Gliricidia sepium). Jurnal Agroteknologi Tropika. 2(2):135-144.

Sim LL. 2005. Microbial community analysis in upflow anaerobic sludge blanket for the treatment of palm oil mill effluent [Master's thesis]. [Iskandar Puteri]: Universiti Teknologi Malaysia. http://eprints.utm.my/i d/eprint/3808.

Suhastyo AA, Anas I, Santosa DA, Lestari Y. 2013. Microbiological studies and chemical properties of local microorganisms (MOL) used in SRI (system of rice intensification) rice cultivation. Sainteks. 10(2):29-39. http: //jurnalnasional.ump.ac.id/index.php/SAINTEKS/ar ticle/view/148/145.

Sutari NWS. 2010. Uji berbagai jenis pupuk cair biourine terhadap pertumbuhan dan hasil tanaman sawi hijau (Brassica juncea L.) [Test various types of biourine liquid fertilizers on the growth and yield of green mustard (Brassica juncea L.)]. Agritrop: Jurnal Ilmu-Ilmu Pertanian. 29(2):75-81.

Tatra AJ. 2010. Pengaruh penambahan beberapa aditif terhadap kualitas silase daun rami (Boehmeria nivea, L. GAUD) [The effect of adding some additives on the silage quality of hemp leaves (Boehmeria nivea, l. gaud); bachelor's thesis]. [Bogor]: Institut Pertanian Bogor.

Thalib A, Bestari J, Widiawati Y, Hamid H, Suherman D. 2000. Pengaruh perlakuan silase jerami padi dengan mikroba rumen kerbau terhadap daya cerna dan ekosistem rumen sapi [Effect of rice straw silage treated with rumen microbes of buffalo on digestibility and ecosystem of cattle rumen]. Jurnal Ilmu Ternak dan Veteriner. 5(1):276-281.

Tillman A, Hartadi H, Reksohadiprodjo S, Prawirokusumo S, Lebdosoekojo S. 1991. Ilmu makanan ternak dasar [Basic animal feed science]. Yogyakarta: UGM Press. 